Bulgarian Academy of Sciences. Space Research and Technology Institute. Aerospace Research in Bulgaria. 33, 2021, Sofia

DOI: https://doi.org/10.3897/arb.v33.e07

\title{
APPLICATION OF GNSS AND SAR DATA IN LANDSLIDE MONITORING ALONG THE BLACK SEA COAST OF BULGARIA
}

\author{
Mila Atanasova ${ }^{1}$, Hristo Nikolov ${ }^{2}$, Keranka Vassileva ${ }^{3}$ \\ ${ }^{I}$ National Institute of Geophysics, Geodesy and Geography - Bulgarian Academy of \\ Sciences \\ ${ }^{2}$ Space Research and Technology Institute - Bulgarian Academy of Sciences \\ ${ }^{3}$ Faculty of Physics, Sofia University "St. Kliment Ohridski", \\ e-mail: mila_at_zl@abv.bg
}

Keywords: GNSS Data, SAR Data, Black Sea Coast, Landslide Processes

\begin{abstract}
Landslide processes are considered the major part of the natural hazards occurring on the northern part of the Bulgarian sea side. Their monitoring can be done with high precision using GNSS data. The objective of this study is to provide solid grounds for monitoring of the landslide processes using GNSS and SAR data. This goal will be achieved by the implementation of the following: 1) establishment a verified methodology for extracting high-quality information from SAR images aimed at continuous monitoring of landslide areas integrating InterFerometric Images (IFI) and GNSS data and 2) creation of a working prototype of an information system for monitoring and prevention of the effects of earth crust movements (landslides, falls, etc.) based on freely accessible data provided by ESA and national sources. One of the scientific tasks to be solved includes the development of methodological approaches for comparison of the results from combined processing of interferometric images from SAR, measurements at permanent GNSS stations of the national NIGGG network in the area of study and geodetic measurements of a newly established test network covering a specific area on the Northern Black Sea coast of Bulgaria with active landslide processes.
\end{abstract}

\section{Introduction}

The main objective of this research is to monitor the ongoing landslide processes by complementary use of Synthesized Aperture Radar (SAR) and Global Navigation Satellite Systems (GNSS) data. It will be achieved by means of proved methodology for continuous monitoring of landslide areas by integrating information from interferometric images (IFIs) and GNSS data from permanent and local geodetic networks. The outcome of this study will deliver reliable information for the ongoing risky geo-processes for the region of the Northeastern Bulgaria, which is known with several large active landslides. These results could provide a better understanding of the origin and dynamics of current landslide processes as well as assessing the resulting hazards by creating thematic maps. The 
selection of the mentioned area is based on information provided by the national authority responsible for the monitoring of the landslides according to which their number has almost doubled over the past two years.

In this study, the selected landslides are located at the coastal zone of $\mathrm{NE}$ Bulgarian Black Sea. The selected region is based on the fact that until now more than 120 landslide events have been registered in the districts of Varna and Dobrich, and $80 \%$ of landslides affect the coastal line. As a contributing factor provoking the interest of this specific area is the weak stability of its slopes, which can be impaired even by single events such as abrasion, erosion, prolonged rainfalls, seismic, etc.

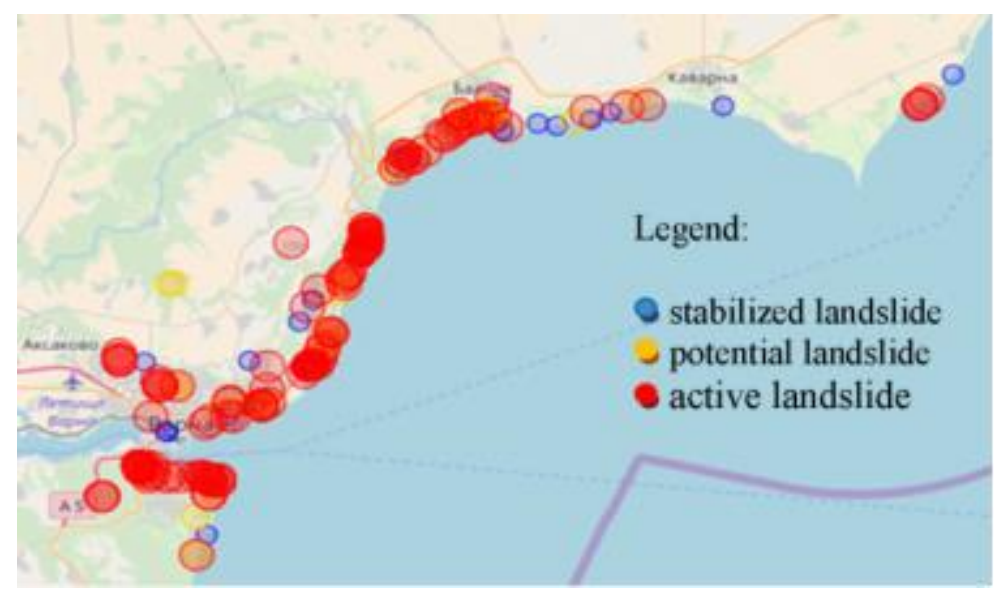

Fig. 1. Map of active, stabilised and potential landslides in NE Bulgaria (according to GIS of the Ministry of Regional Development and Public Works (MRDPW) (http://gis.mrrb.government.bg/)

At present, the authors have investigated a short strip along the Black Sea starting from city of Varna and ending at Kaliakra cape. The area is about $80 \mathrm{~km}$ long, where large numbers (more than 120) of irregularly distributed landslides have been registered and monitored by the competent authorities of MRDPW (Fig. 1). From the geological perspective, most of the landslides located in this region are of complex nature $[1,2]$.

Obtaining reliable data and delivery of an adequate information about the ongoing risky geo-processes of the Earth's surface is a key factor in tracking the origin and dynamics of landslide processes as well as assessing the resulting threats to the population and infrastructure. This is the main reason for the development and implementation of a rapid and accurate method for their operational monitoring. In this paper proposed is a possible solution for estimation of the ground motions caused by landslides based on information derived from differential interferometric processing of SAR data. It was proved that the Earth's 
crust deformations can be registered with the magnitude of centimetres by this method [3]. Results from SAR data processing unambiguously indicate these movements in certain zones of the investigated areas, but GNSS measurements are also required to obtain validated information. The main objective of this research is formulated as follow - to study of the landslide processes by using innovative methods. It was achieved through the extraction of high-quality and reliable information from SAR images focused on regular monitoring of landslide areas and integrating IFIs and GNSS data. Based on the freely available SAR data and the software provided by ESA, as well as data from national sources, a prototype of an information system was elaborated on the basis of archive IFIs produced for monitoring the movements of the Earth's crust (landslides, subsidence, etc.).

In the past decades the northeastern Black Sea coast of Bulgaria has been the subject of scientific research and geodetic surveying by the former "Laboratory of Geotechnics" BAS and "Central Laboratory of Higher Geodesy" today, the Department of Geodesy. By the mid-1990s a geodynamic network was built for monitoring the landslide processes around the town of Balchik [4]. Due to intensive construction activities of the coastal area in the last 20 years and the lack of funding for research and its maintenance, some of the points of the mentioned network (pillars for precise instrument positioning) were destroyed and do not exist. Nevertheless, an extensive and comprehensive methodology for geodetic investigations of landslides was developed [5]. In it underlined is the significance of the type, size and form of the landslide, the velocity of the displacements, the availability of stable areas in the vicinity of the study object, a type of equipment to be used according to the necessary precision.

\section{Materials and Methods}

\section{Synthetic Aperture Radar (SAR) Data and DInSAR Processing}

In this section, a short description of the SAR data and the processing steps used to produce interferometric images (IFIs) that were combined with the geodetic data in studying landslides is presented. The SAR data that have been processed are from a constellation comprised two satellites (A and B) of the Sentinel-1 mission freely distributed by ESA and were obtained from Scientific Data Hub maintained by ESA [6]. Each satellite has revisiting time of 12 days, which means that one and the same area is imaged every 6 days by a satellite. The SAR instrument onboard the satellite is C-band radar (corresponding to a wavelength of $5.56 \mathrm{~cm}$ ) with a right-looking line of sight (LOS) regardless of the orbit direction. It operates in four acquisition modes stripmap, interferometric wide swath (IW), extra-wide swath and wave mode. For interferometric processing single look complex (SLC) data obtained in IW mode must be used since in it not only the amplitude of the backscattered signal is available, but its phase signal too. The phase signal is of crucial importance since after appropriate processing it delivers information about 
the changes in the distance to the objects on the Earth's surface between two satellite overpasses [3].

The DInSAR (differential interferometric SAR data processing) is a method that uses SLC SAR data to produce topographic and surface motion maps based on information contained in the interferometric phase. It is based on the acquisition of complex-valued data over the same area at different times and uses the difference found in the phase signal to detect the horizontal/vertical changes caused by ground deformations. Since in the measured phase, there are two components - one corresponding to the distance of a single object from the surface and the next reflecting the phase changes caused by the environment - a measure of quality, known as coherence, is introduced, which is an estimate of the noise level present in the phase signal. It is widely accepted that for the single pixel from the phase band of the produced IFI to be considered reliable the same pixel in the coherence band should have value above 0.3. Low values of this parameter are due to many external factors such as the state of the troposphere at the time of acquisition, the position of the satellites in their "orbital tube", which defines perpendicular baseline, presence of vegetation in the area of study, etc.

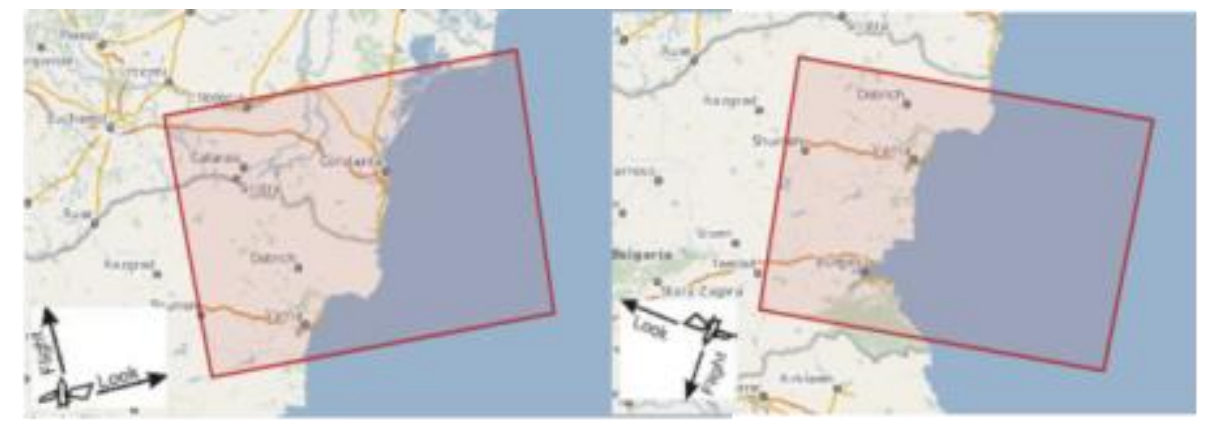

A) Ascending orbit 058

B) Descending orbit 036

Fig. 2. Shape of the SAR images from the ascending (A) and descending orbits (B)

It needs to be underlined that the information provided by the phase signal is a relative concerning one of the SAR images, often called "master", and concerning a point on the ground, which is assumed to be stable. One more thing that needs to be addressed here is that all detected deformations are measured along the LOS of the SAR instrument and for this reason additional calculations are needed for properly combining GNNS and SAR data to obtain vertical ground deformations.

A drawback of the SAR data that need mention is that they cannot detect ground changes along the track of the satellite, which results in better registering movements in the east-west direction, then in north-south. This can be overcome by combining information derived from IFIs from both ascending and descending 
orbits (Fig. 2). An advantage offered using the DInSAR method is the possibility to register ground changes over large or difficult-to-access areas, thus delivering more information than by in situ GNSS acquisitions. This does not mean that it can completely substitute terrain measurements, but rather to provide details on the surface movements for larger areas in the investigated region.

The processing of SAR data for the production of a deformation maps includes the following steps - precise co-registration based on the orbital data of the two images used in the IFI, formation of the interferogram, filtering and speckle reduction, phase unwrapping, and geocoding. The most important step in this procedure is the phase unwrapping since only after it the information contained in the phase signal of |the IFI is converted into ground displacements. At this step, by integrating the phase difference between neighbouring pixels at every $2 \pi$ cycles the difference in altitude in LOS is generated after any integer number of altitudes of ambiguity has been deleted.

\section{GNSS for landslide monitoring}

Geodynamic networks established for landslides monitoring generally consist of two types of points - reference or fixed points located on geologically stable terrain and survey points located within the investigated landslide.

To accomplish the objectives of this study geodetic data from these two types of points are necessary. Data from the stable points situated in nondeformable zone are provided by the permanent GNSS network. The newly established points that from geodynamic networks located inside the specific landslide will be measured in few GNNS acquisition cycles. The deformation analysis of those geodynamic networks will be done after the third measurement cycle by applying an appropriate approach [7].

\section{First results and discussion}

The first step to achieve the main objective was to create a local archive with Sentinel-1A/B images for the region of Northeastern Bulgaria, consisting of about 300 SLC images. For mapping deformations in the region of interest interferometric images at intervals of 4 and 8 months were produced.

The stated time intervals were used, since one of the main factors affecting the quality of the produced IFIs is the vegetation and for this reason only autumn and spring scenes were processed. Also most of the landslides activations occur in the said seasons caused by underground water-level change. Another factor that should be accounted before producing IFI is the presence of snow - used data are from days with no snow coverage [8].

In Fig. 3 presented are the displacements found in the IFI produced from image pair from dates Nov 26 $6^{\text {th }}, 2014$ and Dec 27 $7^{\text {th }}, 2015$. On it the detected 
displacements are colored in purpura and coincide with the landslide regions where most of the registered landslides are located (Fig. 5).

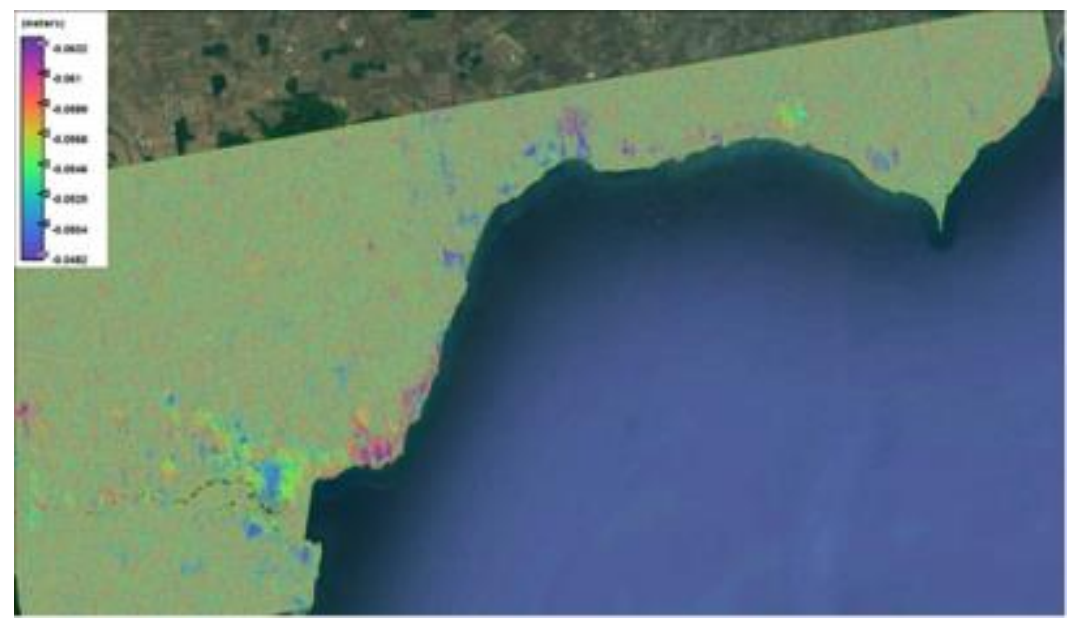

Fig. 3. Displacements obtained from IFI 26Nov2014-27Dec2015

In Fig. 4 are shown the displacements obtained from the IFI Jan $1^{\text {st }}, 2015-$ Dec $21^{\text {st }}, 2016$. The color of the pixel represents the surface movement in metric units for the investigated period ranging from dark blue to purpura. Particularly, vulnerable landslide areas are shown in purpura, less vulnerable in yellow and green. The landslide activity assessment resulting from this research shows (Fig. 4) that the subsidence range from $-48 \mathrm{~mm}$ to $-69 \mathrm{~mm}$.

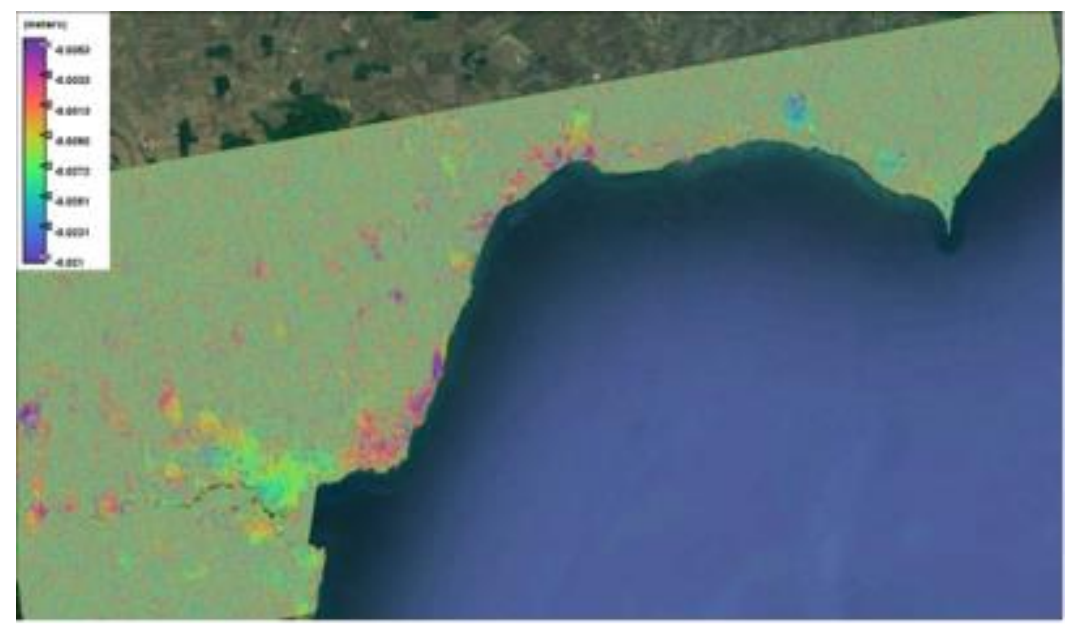

Fig. 4. Ground displacements obtained from the IFI Jan 1st 2015 - Dec 21 st 2016 


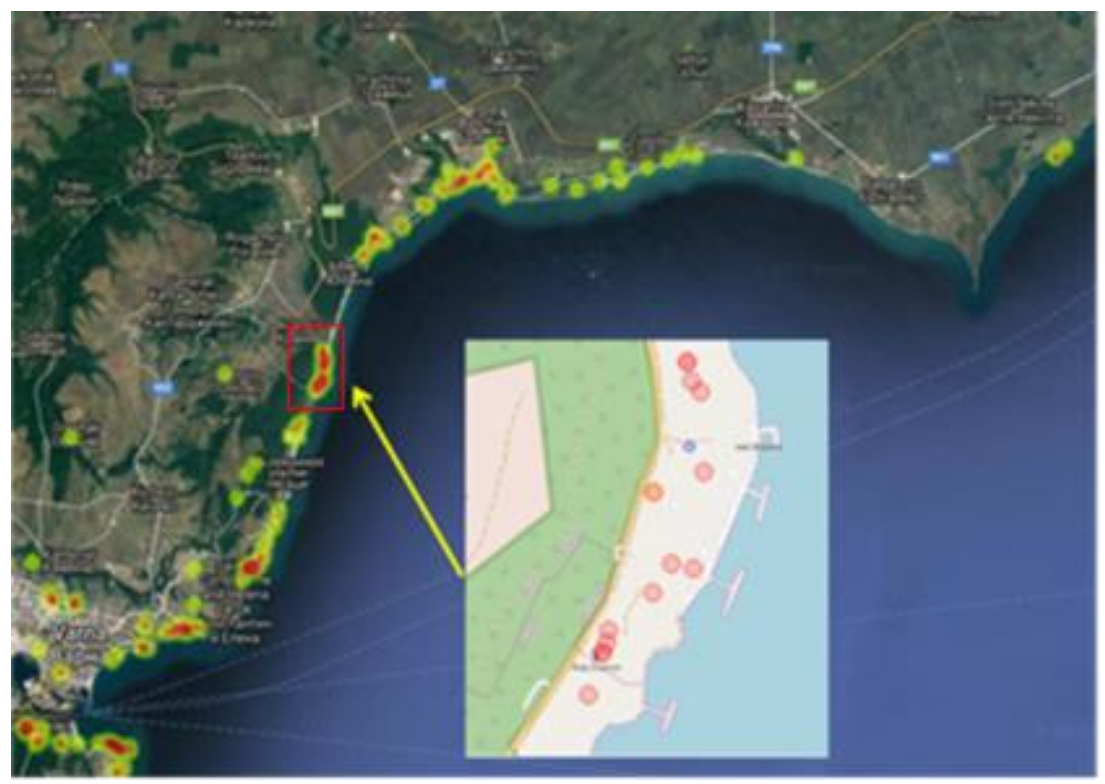

Fig. 5. Raster heat map based on displacement values at the points of landslides registered

The area of interest of this study is the one marked by red quadrate in which the concentration of ground deformations has been observed (Fig. 5). This area is called "Dalgiya yar" - a landslide circus in which several active landslides are located. Since their boundaries overlap, it is difficult to differentiate them from each other. Even for some of the investigated landslides located in this area a smaller landslide could be delineated inside them. This phenomenon can be seen in Fig. 6. In this figure the registration codes of every landslide are shown as they appear in the landslide register maintained by MRDPW and the boundaries of the separate landslides are shown in different colours.

The landslide "Fara" located between the village of Kranevo and the touristic resort "Panorama" covers only the low stage of the circus (Fig. 6). This landslide assigned identification number VAR 02.54145-01-17 in the register of landslides in the Republic of Bulgaria activated on October $13^{\text {th }}$ 2012, destroying the lighthouse and villas. The landslides and collapses in this area that activated in 2013 are largely attributed to the human activities that took place in the last

Twenty years mainly the illegal construction, as well as to the fact that the requirements for civil engineering were not respected. For example, instead of building small bungalow houses two- and three-storey buildings were erected. In some of them, swimming pools have been built whose waters flow down the slope of the landslide. Those flows had very serious impact, as the water from the said pools flows down the slope where there is no drainage. Water supply network 
accidents often occur there, because landslides that tear water mains slip and, in turn, water - regardless of its origin (from the water supply system, rains, or pools) leads to activation and development of landslide and collapse processes.

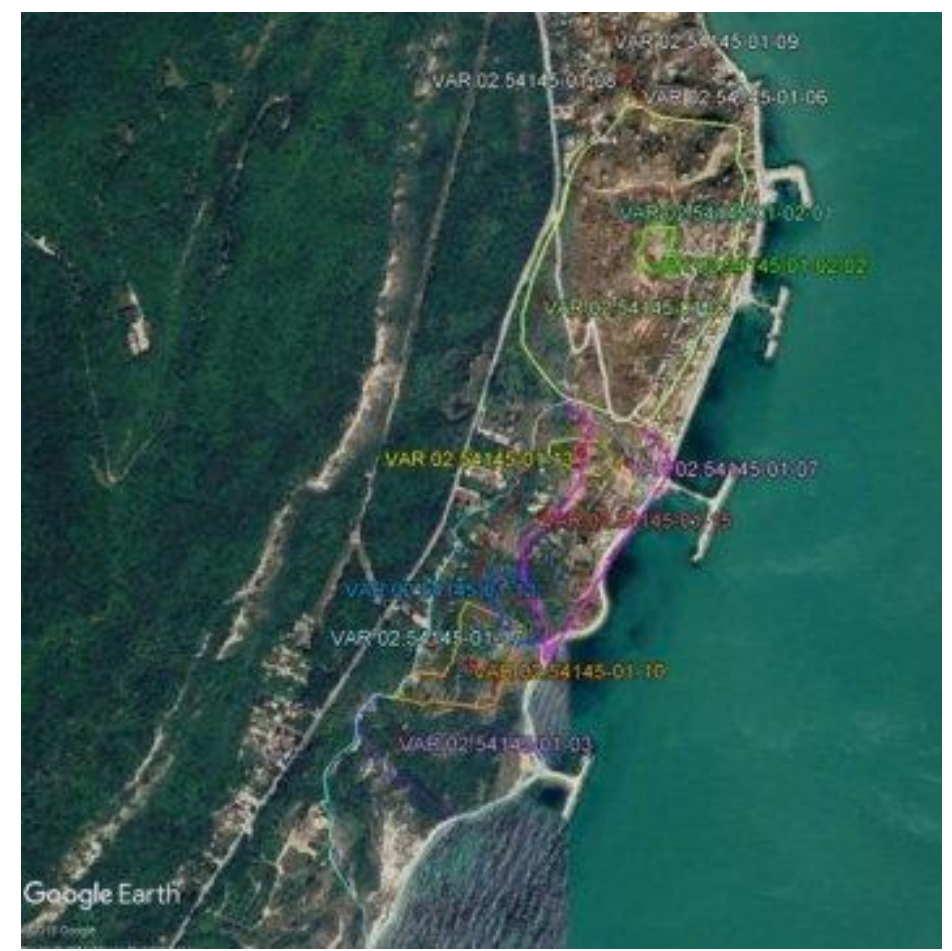

Fig. 6. ID codes from MRDPW register and the boundaries of the investigated landslides in the area of "Fara" landslide

In this research, the authors set their attention on a landslide located in the investigated area - "Dalgiya yar" - "Fara". This specific object was selected since only for it data from previous geodetic measurements and geological observations were made available. This fact made possible the comparison between the in situ data and data obtained from satellites. For landslide "Fara" two measurement cycles were carried out in years 2013 and 2018 of a network consisting of 8 points located on the road I-9 above the landslide. The geodetic data of these points were obtained from Geozashtita Varna Ltd. According to the Contract № RD-02-29372/11.11.2013 under the Law on Public Procurement for Execution assigned by the Ministry of Regional Development to the contractor "Survey Group" Ltd. with subject "Geodetic survey of landslides between bus stop Fara and bus stop Obzor, and Kranevo village" (Fig. 7) [9-11]. 


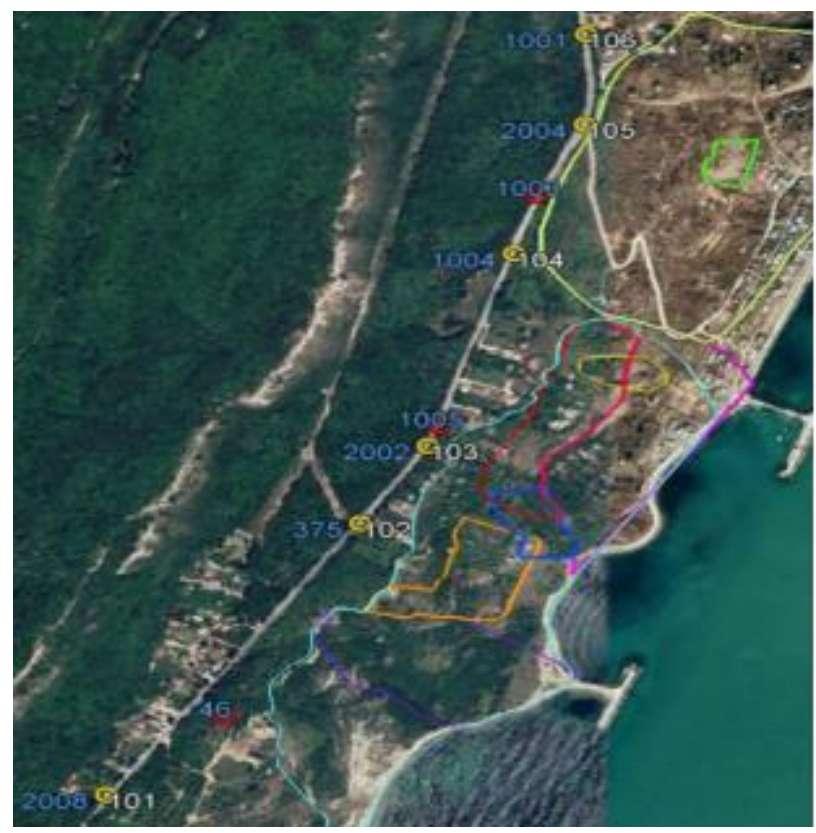

Fig. 7. Geodetic network used by Survey Group Ltd. for determination of displacements along the road (colored in blue)

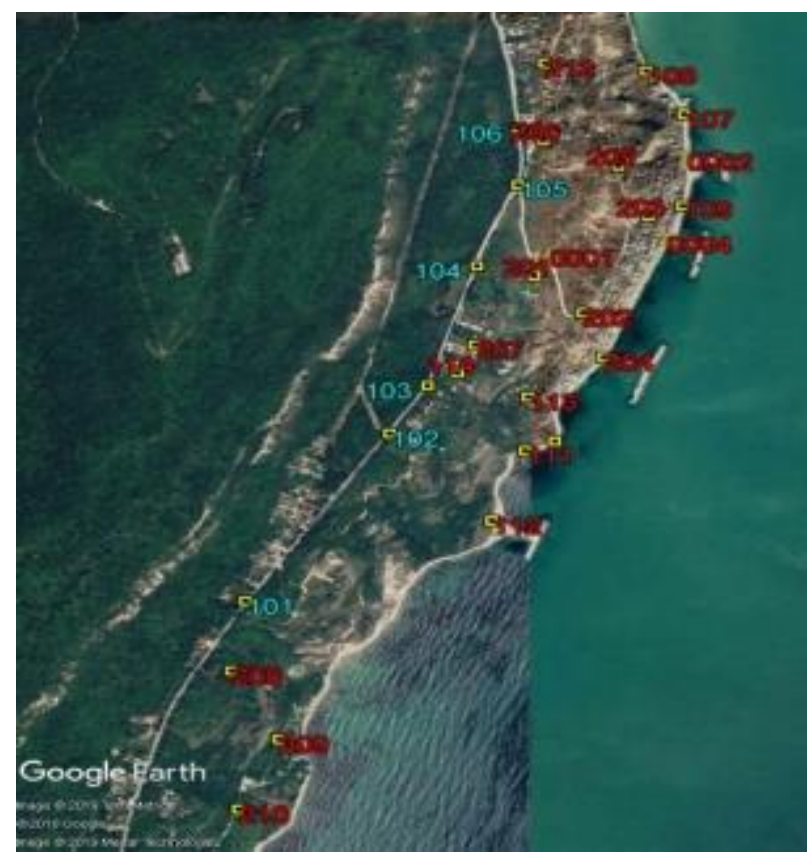

Fig. 8. Points of the new geodynamic network in and around the landslide "Dalgiya yar" 
For this specific study a geodynamic network covering the landslide area "Dalgiya yar" - "Fara" (Fig. 8) was established by the authors. It consists of 30 stabilised points with some being metal pipes $35 \mathrm{~cm}$ long, while other are metal bolts nailed in the rock. The GNSS measurements were carried with 2 receivers of type CHC i80 GNSS with horizontal precision $2.5 \mathrm{~mm}+0.1 \mathrm{ppm}$ RMS and vertical $3.5 \mathrm{~mm}+0.4 \mathrm{ppm}$ RMS and 1 receiver - P3E GNSS sensor used for reference station. The static mode was applied for the GNSS measurements. The two stations of the permanent GNSS network (Varna, Krushartsy) maintained by the private company GeoVara Ltd. and located in the non-deformable zone of the landslide were used as stable points. The newly established geodynamic network (Fig. 8) located inside the landslide will be measured once a year. In the mentioned geodynamic network "Dalgiya yar" all old six points that were found on the terrain from the network used to monitor deformations along the road (blue colored in Fig. 7 and Fig. 8) are included. The first measurement cycle of the geodynamic network was carried out on June 19-23, 2019. Thus, it is the third cycle of measuring the deformations along the road. The results of the GNSS measurements were processed using "CHC Geomatics Office 2" software in the coordinate system WGS84. Since the point coordinates from the measurements made in 2013 and in 2018 are in the national geodetic system 1970, K-7, the software "BGSTrans" was used to transform the points obtained in 2019 into it. This process was done in order to able to use the data in the next processing.

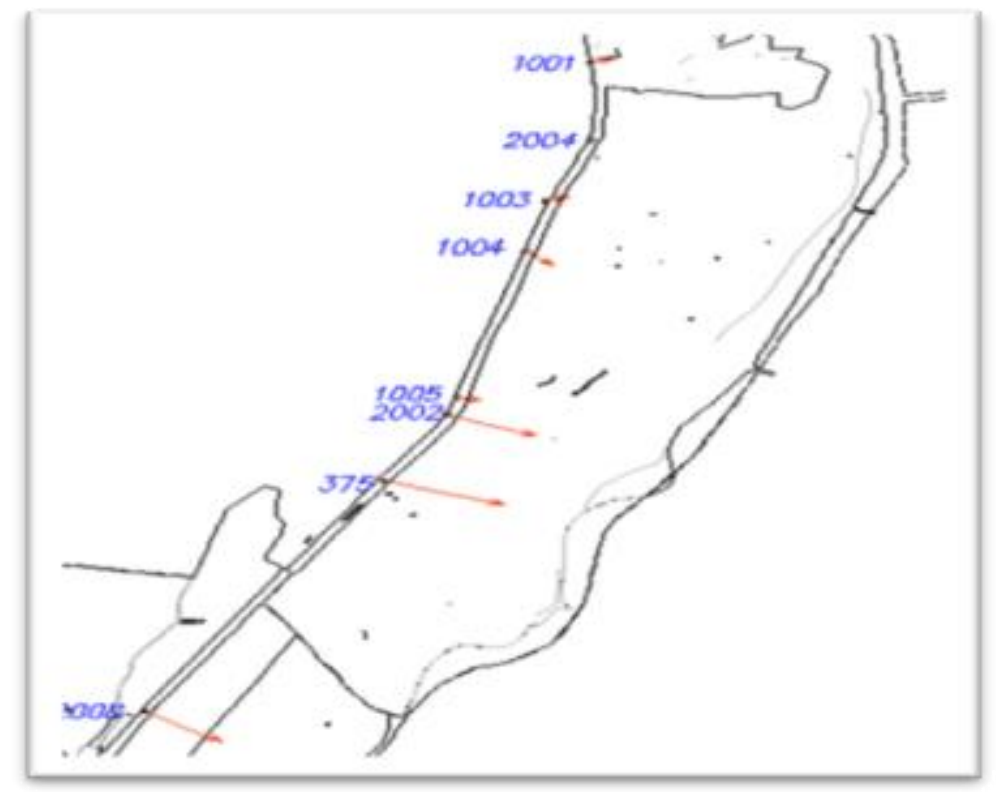

Fig. 9. Horizontal displacements for the period 2018-2013 
Fig. 9 illustrates the horizontal displacements of 8 points along the road I-9. The largest displacements for the area under consideration were found in the southwest part of the site. The horizontal displacements shown in Table 1 were obtained from the measurements conducted in years 2013, 2018 and 2019.

Table 1. Horizontal $(\Delta D)$ and vertical $(\Delta H)$ displacements for the periods 2018-2013 and 2019-2018

\begin{tabular}{cccccc}
\hline \multicolumn{2}{l}{ Point number } & \multicolumn{3}{c}{ 2019-2013 - 2018 } & \\
\hline old & new & $\Delta D,[\mathrm{~m}]$ & $\Delta H,[\mathrm{~m}]$ & $\Delta D,[\mathrm{~m}]$ & $\Delta H,[\mathrm{~m}]$ \\
\hline 2008 & 101 & 0.607 & -0.088 & 0.085 & -0.056 \\
375 & 102 & 1.034 & -0.465 & 0.094 & -0.072 \\
2002 & 103 & 0.648 & -0.375 & 0.148 & -0.054 \\
1004 & 104 & 0.242 & -0.068 & 0.105 & -0.074 \\
2004 & 105 & & & 0.092 & 0.019 \\
1005 & & 0.164 & -0.038 & & \\
1003 & & 0.159 & 0.017 & & \\
1001 & 106 & 0.139 & 0.054 & 0.087 & -0.037 \\
\hline
\end{tabular}

Horizontal deformations obtained for the period 2013-2018 along the road I-9 are in the range from 0.61 to $1.04 \mathrm{~m}$ and vertical ones are in the range between 0.088 up to $0.465 \mathrm{~m}$. It was established that the overall movement of the terrain located in the southwestern part of the area after a turn of the road I-9 (points 2002, 375 , and 2008). The maximum displacements are at the point 375 - horizontal $1.034 \mathrm{~m}$ and vertical $-0.465 \mathrm{~m}$. In the northern part of the road I-9 (points 1001, $1003,1004)$ slight movements of the terrain were obtained that are in the range from $0.139 \mathrm{~m}$ to $0.242 \mathrm{~m}$ in the horizontal plane and from 0.05 to $-0.07 \mathrm{~m}$ in height.

For the II $^{\text {nd }}$ period (2018-2019), which is only 10 months long, the deformations have lower values ranging from 0.085 to $-0.148 \mathrm{~m}$ in the horizontal plane and in vertical the maximum is $0.074 \mathrm{~m}$.

The obtained first results of the landslides investigation presented in this paper can be summarised as follows:

1. Extensive research was performed on the recent activations of landslides and old and new geodetic data concerning the deformations were selected;

2. A local image archive of Sentinel-1 satellites was created for the region of Northeastern Bulgaria; 
3. A set of interferometric images was created at fixed intervals monthly, every 4 months, 8 months, a year;

4. Thematic interferometric images used in mapping deformations for the region of Northern Black Sea coast are generated,

5. The relationship between geodetic and satellite derived information concerning ongoing landslide processes is confirmed.

\section{Conclusions}

On the basis of the obtained results from processing GNSS and SAR data, it can be concluded that both used data sources lead to similar results (the registered displacements are in the range of centimeters) and they confirm the overall behaviour of the landslides under study. The differences between them could be explained by the large number of external factors affecting SAR data such as vegetation and temporal decorrelation. When comparing the two methods, it should also be taken into account that the values of the IFIs elements correspond to a much larger area $(15 \times 15 \mathrm{~m})$, while the GNSS refers to point measurements. Nevertheless, the results of this study are encouraging and the authors will continue their research on the investigation of the landslide zones using SAR data. Another factor that supports the usage of IFIs in landslides investigation is that the price and the man effort are much lower than those necessary for GNSS measurements.

\section{Acknowledgements}

This paper has been made available with the financial support provided by the National Science Fund, call identifier "Financial support for basic research projects on societal challenges - 2018" Project number КП-06-ОПР 06/1. The authors would like to express their gratitude to GeoVARA Ltd, Geozastita Varna Ltd., Ministry of Regional Development and Public Works и Survey Group Ltd. for the provided data.

\section{References}

1. Berov, B., Pl. Ivanov, N. Dobrev, R. Nankin, and M. Krastanov. State of the Art for Landslides Along the North Bulgarian Black Sea Coast, Landslide Science and Practice, Volume 5: Complex Environment, Springer, Editors: Claudio Margottini, Paolo Canuti, Kyoji Sassa, 2013, 97-102.

2. Bruchev, I., N. Dobrev, G. Frangov, Pl. Ivanov et al. The landslides in Bulgaria factors and distribution, Geologica Balcanica, 2007, 36, 3-4, 3-12.

3. Luis, V. 2016. TOPS Interferometry Tutorial, http://sentinel1.s3.amazonaws.com/docs/S1TBX\%20TOPSAR\%20Interferometry \%20with\%20Sentinel-1\%20Tutorial.pdf (accessed January 2019) 
4. Tsenkov, T. Assessment of the use of geodetic methods in the study of landslides, abrasion and erosion. Journal of the Bulgarian Geological Society, Laboratory of Geotechnics - BAS, 1993, LIV, 1, (in Bulgarian)

5. Milev, G., T. Tsenkov, M. Avdzhiev et al. Instruction for the study of landslides by geodetic methods, Sofia, GUKK, 143 p., 1987 (in Bulgarian).

6. Copernicus Open Access Hub. https://scihub.copernicus.eu/dhus/\#/home (accessed January 2019)

7. Vassileva, K., G. Valev, and M.Atanasova-Zlatareva. Deformation analysis of the Balkan Peninsula from GPS data 2011-2016. Coordinates, XIII, 12, Thomson Press (India), 2017, 31-34, ISSN: 0973-2136.

8. Stringmeteo. https://www.stringmeteo.com/ (accessed January 2019)

9. Geozastita - Varna Ltd., Annual Report under Contract No РД-02-29-198 / 02.05.2018 and Additional Agreement № РД-02-29-198 (1) / 06.11.2018 Preventive activities related to registration and monitoring of the landslide areas on the territory of the Republic of Bulgaria and areas with abrasive processes along the Black Sea coast in the regions of Dobrich, Shumen, Varna, Burgas (in Bulgarian), 2018

10. Ministry of Regional Development and Public Works, Map of landslide, http://gis.mrrb.government.bg/

11. Ministry of Regional Development Contract № RD-02-29-372/11.11.2013 "Geodetic survey of landslides between bus stop Fara and bus stop Obzor, and Kranevo village". Contractor "Survey Group" Ltd.

\title{
ПРИЛОЖЕНИЕ НА ДАННИ ОТ ГНСС И РСА ЗА МОНИТОРИНГ НА СВЛАЧИЩА ПО ЧЕРНОМОРСКОТО КРАЙБРАЖИЕ НА БЪЛГАРИЯ
}

\author{
М. Атанасова, Х. Николов, К. Василева
}

\begin{abstract}
Резюме
Свлачищните процеси се считат за основна част от природните опасности, възникващи в северната част на българското черноморско крайбрежие. Техният мониторинг може да се реализира с висока точност, като се използват данни от глбални навигационни спътникови системи (ГНСС). Целта на това изследване е да предостави надеждни резултати при мониторинг на свлачищните процеси, използвайки данни от ГНСС и радари със синтезирана апертура (РСА). Тя ще бъде постигната чрез прилагане на: 1) създаване на доказана методика за извличане на висококачествена информация от РСА изображения, насочена към непрекъснат мониторинг на свлачищните зони, интегриращи интерферометрични изображения (ИФИ) и данни от ГНСС, и 2) създаване на работещ прототип на информационна система за наблюдение и предотвратяване на ефектите от движението на земната кора (свлачища,
\end{abstract}


пропадания и др.) базирана на свободно достъпни данни предоставени от EКА и национални източници. Една от научните задачи, които трябва да бъдат решени включва разработването на методологични подходи за сравнение на резултатите от комбинирана обработка на интерферометрични изображения от РСА, измервания от националната мрежа перманентни ГНСС станции на Националния институт по геофизика, геодезия и география, намиращи се в изследвания район, както и геодезически измервания на новосъздадена тесто-ва геодинамична мрежа, обхващаща конкретна зона по Северното Черноморие на България, в която са проявени активни свлачищни процеси. 